\title{
ZAKRES OCHRONY KONSUMENTA W UBEZPIECZENIU OD UTRATY ŹRÓD ŁA DOCHODU OFEROWANYM PRZEZ WYBRANE BANKI
}

\author{
mgr Katarzyna Nowak \\ Szkoła Doktorska, Uniwersytet Ekonomiczny w Krakowie \\ ORCID: https://orcid.org/0000-0002-9316-616X
}

\begin{abstract}
Streszczenie
Powszechną praktyką na rynku finansowym jest łączenie przez banki w ofertach produktów kredytowych i ubezpieczeniowych. Ubezpieczenie kredytu to połączenie dwóch skomplikowanych usług finansowych usługi bankowej oraz usługi ubezpieczeniowej. Dystrybucja produktów ubezpieczeniowych wraz z kredytami jest zjawiskiem naturalnym. Kredyt i ubezpieczenie to dobra komplementarne. Rata kredytu stanowi na ogół poważny wydatek w budżecie gospodarstwa domowego. W konsekwencji zaciągnięcia kredytu rośnie ryzyko utraty zdolności kredytobiorcy do wywiązania się ze zobowiązań finansowych. W tym celu kredytobiorca ma do dyspozycji ubezpieczenie jako narzędzie ograniczające to ryzyko. Jednakże propozycja ubezpieczenia wychodzi z reguły ze strony banku i jest motywowana jego interesem. Banki traktują umowę ubezpieczenia jako formę zabezpieczenia spłaty kredytu, która stanowi zabezpieczenie dodatkowe, ale często też jest zabezpieczeniem jedynym. Z kolei dla konsumenta jest to instrument, który może okazać się pomocny, kiedy znajdzie się w trudnej sytuacji finansowej spowodowanej utratą pracy czy trwałym inwalidztwem. Celem ubezpieczeń dodawanych do kredytów przez banki jest ograniczanie ryzyka, jakim jest niezdolność kredytobiorcy do spłaty kredytu oraz zapewnienie bezpieczeństwa ubezpieczonym lub uposażonym. Ubezpieczenie ze względu na swój charakter nie jest typowym produktem na rynku finansowym, ponieważ ubezpieczający nabywa abstrakcyjną gwarancję wypłaty świadczenia w zamian za składkę ubezpieczeniową. Celem artykułu jest porównanie i ocena zakresu ochrony konsumenta (ubezpieczającego) na podstawie zapisów ogólnych warunków ubezpieczenia w ubezpieczeniu od utraty źródła dochodu dodawanego do kredytów konsumenckich przez dwa największe banki w Polsce. Badanie to pozwoli na określenie formalnych ram ochrony ubezpieczeniowej. Do analizy porównawczej zakresu ochrony ubezpieczeniowej z ogólnych warunków ubezpieczenia zostały wybrane następujące kategorie: przedmiot ubezpieczenia, definicje zdarzeń objętych odpowiedzialnością zakładu ubezpieczeń, charakter świadczeń oraz wyłączenia i ograniczenia odpowiedzialności. Powyższa analiza zakresu ochrony ubezpieczeniowej w wybranych bankach dowodzi, że oferowane ogólne warunki ubezpieczenia cechują się wysokim stopniem skomplikowania. Dlatego konsument może mieć problem z porównaniem ofert i wybraniem ubezpieczenia użytecznego, czyli dopasowanego do jego potrzeb.
\end{abstract}

Słowa kluczowe: kredyt mieszkaniowy, ubezpieczenie, zabezpieczenie kredytu, bancassurance, ochrona konsumenta.

JEL Class: D18, G21, G22. 


\section{WSTĘP}

Banki w ramach współpracy z zakładami ubezpieczeń (bancassurance) oferują ubezpieczenia, które mają chronić kredytobiorców (konsumentów) przed ryzykiem utraty zdolności do spłaty kredytu. Wśród ubezpieczeń łączonych z kredytem, oferowanych przez banki, znajdują się zarówno ubezpieczenia osobowe, jak i majątkowe. Należą do nich: ubezpieczenia na życie i zdrowie, na wypadek utraty dochodu, na wypadek ognia i innych zdarzeń losowych oraz obecnie stosunkowo rzadko zawierane ubezpieczenia niskiego wkładu własnego i ubezpieczenia pomostowe. Ubezpieczenie kredytu nie jest obowiązkowe, ponieważ żadne przepisy prawa takiego obowiązku na kredytobiorców nie nakładają. Banki mogą natomiast wymagać dowolnego zabezpieczenia przewidzianego przepisami prawa, $\mathrm{w}$ tym ubezpieczenia. W Polsce banki mają w ofercie kredyty z ubezpieczeniem lub bez. Kredyt $z$ ubezpieczeniem jest niżej oprocentowany, ale kredytobiorca nie może skorzystać z ubezpieczyciela nierekomendowanego przez kredytodawcę, bez pogorszenia warunków kredytu.

Dystrybucja produktów ubezpieczeniowych wraz z kredytami jest zjawiskiem naturalnym. Kredyt i ubezpieczenie to dobra komplementarne. Zaciągnięcie kredytu podnosi ryzyko finansowe kredytobiorcy. W tym celu kredytobiorca ma do dyspozycji ubezpieczenie jako narzędzie ograniczające to ryzyko.

Zawarcie umowy ubezpieczenia przez kredytobiorcę (ubezpieczającego) następuje na podstawie doręczonych przez zakład ubezpieczeń ogólnych warunków ubezpieczenia.

Istota umowy ubezpieczenia jako kontraktu najwyższego zaufania oparta jest na zapewnieniu pomocy poszkodowanym. Pewność ochrony jest fundamentem ubezpieczeń. Każdy przypadek odmowy wypłaty świadczenia podważa zaufanie konsumentów do zakładów ubezpieczeń. [P. Nowak 2019: 57-67].

Celem artykułu jest porównanie i ocena zakresu ochrony konsumenta (ubezpieczającego) na podstawie zapisów ogólnych warunków ubezpieczenia w ubezpieczeniu od utraty źródła dochodu dodawanego do kredytów konsumenckich w Banku PKO BP SA i w Banku Pekao SA. Badanie to pozwoli na określenie formalnych ram ochrony ubezpieczeniowej. Do analizy porównawczej zakresu ochrony ubezpieczeniowej z ogólnych warunków ubezpieczenia zostały wybrane następujące kategorie: przedmiot ubezpieczenia, definicje zdarzeń objętych odpowiedzialnością zakładu ubezpieczeń, charakter świadczeń oraz wyłączenia i ograniczenia odpowiedzialności.

Studia literatury przedmiotu, analiza aktów prawnych i poglądów doktryny pozwoliły na postawienie tezy, iż postanowienia wzorców umów ubezpieczenia powiązanych z umową kredytu konsumenckiego cechuje wysoki stopień skomplikowania i tym samym utrudniają konsumentowi dokonania oceny i wyboru użytecznego ubezpieczenia. 
Artykuł został oparty na analizie literatury przedmiotu. W artykule została przeprowadzona analiza porównawcza zapisów ogólnych warunków ubezpieczenia (o.w.u.) dostępnych w ofercie wybranych banków. Dodatkowe dane pozyskano w ramach przeprowadzonych bezpośrednich rozmów informacyjnych z pracownikami tych banków.

\section{CHARAKTERYSTYKA PRAWNA OGÓLNYCH WARUNKÓW UBEZPIECZENIA}

Źródłem powstania stosunku prawnego ubezpieczenia jest umowa ubezpieczenia. Zawarcie umowy ubezpieczenia następuje najczęściej poprzez przystąpienie ubezpieczającego do warunków przedstawionych przez ubezpieczyciela. W takim wypadku rola ubezpieczającego w kształtowaniu indywidualnych warunków umowy jest zazwyczaj ograniczona do minimum, ponieważ ubezpieczający może jedynie zawrzeć umowę i jednocześnie zgodzić się na warunki określone w umowie albo w ogóle zrezygnować z jej zawarcia. W związku z tym umowa ubezpieczenia jest umową adhezyjną [Kwiecień 2016: 56; Orlicki 2010: 128; Serwach 2014: 99-119], gdzie warunki umowy określa jeden z kontrahentów (zakład ubezpieczeń) i nie przewiduje on możliwości negocjacji treści umowy i dopasowania umowy do indywidualnych potrzeb i wymagań ubezpieczającego.

Zawarcie umowy ubezpieczenia następuje na podstawie doręczonego przez zakład ubezpieczeń wzorca umownego, czyli ogólnych warunków ubezpieczenia (dalej jako o.w.u.). Przepisy kodeksu cywilnego [Ustawa z dnia 23 kwietnia 1964 r..., t.j. Dz.U. 2019, poz. 1145 ze zm.], (dalej jako k.c.), nie określają terminu jaki powinien zostać zachowany pomiędzy doręczeniem o.w.u. a zawarciem umowy ubezpieczenia. Bez wątpienia ubezpieczyciel powinien udostępnić wzorzec przed podpisaniem umowy, aby konsument miał możliwość zapoznania się z jego treścią.

Wzorzec umowy w postaci o.w.u. zawiera usystematyzowane, standardowe postanowienia, które mają zastosowanie do zawieranych przez ubezpieczyciela tzw. umów masowych [Przybitnikowski 2019: 123], których stosowanie ma wykraczać poza jeden przypadek [Zoll 1998: 46-63; Łętowska: 2004] oraz które cechuje powtarzalna, zestandaryzowana treść. Zakład ubezpieczeń ma prawo stworzyć własne zasady ochrony ubezpieczeniowej, definicje pojęć, czy sposoby wyliczania kwoty wypłacanej w momencie zaistnienia wypadku ubezpieczeniowego. Jednakże postanowienia zawarte w takim wzorcu nie mogą być sprzeczne z bezwzględnie obowiązującymi przepisami [Orlicki 2016: 75-87; Wąsiewicz 1997: 103].

W literaturze przedmiotu wzorzec umowny został określony jako ,jednostronne i przygotowane przed zawarciem umowy, gotowe zestawienie klauzul umownych, przeznaczonych do wykorzystania w nieograniczonej liczbie 
przypadków" [Kościelniak 2011]. Z przytoczonej definicji wynika, że przed zawarciem umowy ubezpieczenia zakład ubezpieczeń (proponent) formułuje wzorzec, a druga strona umowy (adherent) nie ma wpływu na treść klauzul. To ubezpieczyciel wywiera największy wpływ na zakres i poziom ochrony ubezpieczeniowej przy jednoczesnym biernym udziale ubezpieczającego w kształtowaniu treści stosunku prawnego łączącego go z ubezpieczycielem. Stosowanie wzorców umownych $\mathrm{w}$ znaczącym stopniu ogranicza ingerencję konsumentów w treść umowy ubezpieczenia. W takiej sytuacji ubezpieczyciel może nadużywać swojej dominującej pozycji i narzucać warunki ubezpieczenia poprzez formułowanie korzystnych dla siebie treści wzorców kosztem interesu klientów.

W polskiej doktrynie dominuje pogląd, że wzorzec umowy nie jest częścią umowy ubezpieczenia, a kwalifikowanym oświadczeniem woli, który kształtuje treść stosunku prawnego poza konsensem stron [Wałachowska 2016: 3-12; Bednarek i Mikłaszewicz: 2020].

Wzorzec umowy jest dokumentem zewnętrznym w stosunku do umowy ponieważ umowa ubezpieczenia zawiera postanowienia indywidualne. Indywidualizacja postanowień $\mathrm{w}$ przypadku umów zawieranych na podstawie doręczonego wzorca polega na określeniu stron umowy, przedmiotu świadczenia, ceny ubezpieczenia oraz czasu trwania umowy. Pozostałe prawa i obowiązki stron reguluje o.w.u. i nie podlegają one indywidualnemu uzgodnieniu.

W przepisach kodeksu cywilnego regulujących umowę ubezpieczenia (art. 805 k.c. i nast.), ustawodawca posługuje się pojęciem ogólnych warunków ubezpieczenia, jako źródła regulacji stosunku ubezpieczenia [Pokrzywniak 2016: 33-46]. Natomiast w ustawie o działalności ubezpieczeniowej i reasekuracyjnej [Ustawa z dnia 11 września 2015 r... t.j. Dz.U. z 2019 r. poz. 381 ze zm.] (dalej jako u.d.u.r.) ustawodawca odnosi się nie tylko do ogólnych warunków ubezpieczenia, ale również używa sformułowania ,inne wzorce umowy”. Jak zauważa M. Krajewski [2016: 13-25], w kodeksie cywilnym mianem ogólnych warunków ubezpieczenia określa się wszelkie wzorce umowy, które są stosowane przez ubezpieczyciela. Dlatego również do innych wzorców będą miały zastosowanie przepisy k.c., w których ustawodawca posługuje się pojęciem ogólnych warunków ubezpieczenia.

Przepisy k.c. nie przewidują żadnych wymogów odnośnie treści ogólnych warunków ubezpieczenia. Jednakże minimalny zakres elementów, które są obowiązkowe w o.w.u. został wyszczególniony w art. 16 u.d.u.r. W szczególności o.w.u. powinno określać: rodzaj ubezpieczenia i jego przedmiot, prawa i obowiązki każdej ze stron umowy ubezpieczenia, zakres odpowiedzialności zakładu ubezpieczeń, sposób ustalania i opłacania składki ubezpieczeniowej [Celczyńska i in. 2016: 50].

Postanowienia zawarte we wzorcu oraz w umowie powinny być zrozumiałe oraz sformułowane w sposób jednoznaczny, co wynika wprost $\mathrm{z}$ art. $385 \S 2$ k.c. oraz $\mathrm{z}$ art. 15 ust. 3. u.d.u.r. Zrozumiałość oznacza łatwość zrozumienia treści, 
czyli jasność użytych sformułowań. Jednoznaczność oznacza, że postanowienia nie powinny wzbudzać wątpliwości interpretacyjnej. Zasada przejrzystości (transparentności) wzorca odnosi się również do precyzyjnego określania zakresu ubezpieczenia oraz dokładnego wskazania wyłączeń odpowiedzialności ubezpieczyciela. Kluczowy dla zachowania tej zasady jest również sposób definiowania pojęć o istotnym znaczeniu.

Wymóg transparentności dotyczy aspektów językowych oraz aspektów technicznych wzorca [Mikłaszewicz 2020]. W związku z tym, istotny we wzorcu jest zarówno język, jak i sposób sporządzenia dokumentu. Przy formułowaniu w o.w.u. praw i obowiązków stron oraz innych postanowień powinno się uwzględniać przeciętny poziom wiedzy ubezpieczającego.

Istotą wymogu transparentności jest zapewnienie konsumentowi możliwości przewidzenia skutków postanowień zawartych w o.w.u. [P. Nowak 2020: 183194]. Posługiwanie się prostym i jasnym językiem ma zapewnić konsumentowi podjęcie świadomej decyzji odnośnie zawarcia umowy ubezpieczenia.

W przypadku zastosowania niejasnych postanowień we wzorcu tłumaczy się je na korzyść słabszej strony - ubezpieczającego, ubezpieczonego, uposażonego lub uprawnionego. Ubezpieczyciel jako podmiot profesjonalny, który redaguje ogólne warunki ubezpieczenia ma obowiązek sformułować je precyzyjnie. „Byłoby sprzeczne z zasadami współżycia społecznego, by konsekwencje niewłaściwej redakcji postanowień obciążały ubezpieczającego" [Wyrok SN dnia 18 marca 2003 r., IV CKN 1858/00].

Celem wprowadzonego wymogu przejrzystości wzorców jest poprawa czytelności ogólnych warunków ubezpieczenia [Orlicki 2015: 55-70] i tym samym zwiększenie świadomości konsumentów odnośnie ich praw i obowiązków. Można przypuszczać, że większość konsumentów nie zapoznaje się z treścią doręczonych wzorców umownych [Więcko-Tułowiecka 2014: 80]. Ich konstrukcja, obszerność treści, jak i język mogą skutecznie zniechęcać konsumenta do czytania, próby zrozumienia czy dokonania analizy zakresu ochrony ubezpieczeniowej.

Popełnione błędy przez konsumenta na etapie oceny zakresu ochrony ubezpieczeniowej i później przy zawieraniu umowy ubezpieczenia mogą być dla niego krytyczne i skutkować nawet brakiem wypłaty świadczenia [K. Nowak 2019: 85-97].

\section{ZAKRES OCHRONY W UBEZPIECZENIACH Z TYTUŁU UTRATY ŹRÓDŁA DOCHODU W BANKU PKO BP I BANKU PEKAO SA}

Ochrona ubezpieczeniowa obejmuje zdarzenia losowe, których wystąpienia nie da się przewidzieć. Zdarzenia losowe są utożsamiane z nieszczęśliwymi wypadkami. Jednakże nie wszystkie wypadki mogą być objęte ochroną ubezpiecze- 
niową. Pewnych ryzyk nie można ubezpieczyć. Co do zasady, ubezpieczeniem nie są objęte wypadki, które nastąpiły przed objęciem ochroną ubezpieczeniową, powstałe $\mathrm{w}$ wyniku naturalnego zużycia lub z przyczyn spowodowanych umyślnie. Ochronie nie podlegają również zdarzenia pewne lub takie, które cechują się ryzykiem trudnym do oszacowania.

Umowę ubezpieczenia zawiera się w związku z ryzykiem przyszłym i niepewnym. Możliwość przewidzenia zajścia zdarzenia nie wyłącza odpowiedzialności ubezpieczyciela. Nie można zawrzeć umowy ubezpieczenia w zakresie ryzyka, które nie może się urzeczywistnić albo jest pewne. Na tym opiera się ubezpieczalność ryzyka.

Analiza zapisów o.w.u. ubezpieczenia od utraty dochodu oferowanego do kredytów mieszkaniowych, dla osób zawierających umowę kredytu została przeprowadzona na podstawie ofert przekazanych przez dwa największe banki w Polsce: PKO Bank Polski SA (dalej PKO BP) oraz Banku Pekao SA (dalej Bank Pekao). Zarówno PKO BP, jak i Bank Pekao są najsilniejszymi bankami pod względem posiadanych aktywów i udzielonych kredytów oraz liczby klientów. Potwierdzają to dane publikowane przez miesięcznik „Bank”, który w ramach corocznie sporządzanego rankingu przedstawia podranking banków, który obejmuje aktywność banków na rynku kredytów hipotecznych dla osób fizycznych. W rankingu za 2018 r. pierwsze miejsca, pod względem wartości portfela kredytów, zajęły PKO BP, Santander, Bank Pekao [XXIV Ranking Banków, 2019: 21]

Ranking banków przygotowuje również corocznie gazeta „Newsweek” wraz z firmą badawczą Millward Brown. W kategorii „bankowość hipoteczna” - w której oceniane jest komu i na jakich warunkach banki skłonne są udzielać kredytów na mieszkania i domy, najlepsze banki to: Bank Pekao, PKO BP, Alior [Ranking przyjazny bank ,Newsweeka”, 2019: 64].

PKO BP i Bank Pekao występują w dystrybucji ubezpieczeń spłaty kredytu $\mathrm{w}$ charakterze agentów ubezpieczeniowych i oferują klientom nabycie ubezpieczenia w ramach zawarcia umowy ubezpieczenia (ubezpieczenie indywidulane). Ubezpieczycielem współpracującym z bankiem PKO BP dla ubezpieczeń spłaty kredytu hipotecznego na wypadek utraty źródła dochodu, inwalidztwa w następstwie nieszczęśliwego wypadku i leczenia szpitalnego jest PKO Towarzystwo Ubezpieczeń SA. Z kolei Bank Pekao oferuje do kredytów mieszkaniowych ubezpieczenia na wypadek utraty dochodu w następstwie nieszczęśliwego wypadku u Sopockiego Towarzystwa Ubezpieczeń ERGO Hestia SA.

Ubezpieczenie spłaty kredytu PKO BP obejmuje trzy zdarzenia:

- utratę źródła dochodu,

- inwalidztwo z tytułu całkowitej fizycznej utraty lub całkowitej trwałej utraty władzy nad poszczególnymi narządami, wymienionymi w dołączonej tabeli w dalszej części o.w.u.,

- leczenie szpitalne. 
Ubezpieczenie spłaty kredytu jest dostępne dla osób otrzymujących dochody na podstawie stosunku pracy, z działalności gospodarczej oraz innej pracy zarobkowej.

Utrata źródeł dochodu z tytułu stosunku pracy oznacza $\mathrm{w}$ treści badanego o.w.u. ,...Utratę dochodu z tytułu stosunku pracy, o ile zostały spełnione łącznie poniższe kryteria:

1) ustanie stosunku pracy nastąpiło z którejkolwiek z poniższych przyczyn:

a) rozwiązania przez pracodawcę stosunku pracy za wypowiedzeniem, przy czym za takie wypowiedzenie nie uważa się rozwiązania stosunku pracy $\mathrm{w}$ trybie wywołującym jedynie skutki rozwiązania stosunku pracy przez pracodawcę za wypowiedzeniem; w tym rozwiązania umowy o pracę przez pracownika $\mathrm{w}$ trybie opisanym $\mathrm{w}$ art. 23(1) § 4 ustawy $\mathrm{z}$ dnia 26 czerwca 1974 r. Kodeks pracy;

b) rozwiązania stosunku pracy na mocy porozumienia stron na podstawie art. 30 wskazanym w $\S 1$ pkt. 1 Kodeksu pracy wyłącznie w związku z art. 1 lub art. 10 ustawy z 13 marca 2003 r. o szczególnych zasadach rozwiązania z pracownikami stosunków pracy z przyczyn niedotyczących pracowników;

c) wygaśnięcia stosunku pracy na skutek śmierci pracodawcy będącego osobą fizyczną albo ogłoszenia przez pracodawcę upadłości albo oddalenia przez sąd wniosku o ogłoszenie upadłości pracodawcy z powodu braku wystarczającego majątku na zaspokojenie kosztów postępowania upadłościowego;

d) wygaśnięcia mandatu w ramach stosunku służbowego;

e) odwołania ze stanowiska lub funkcji $\mathrm{w}$ ramach stosunku służbowego z wyłączeniem sytuacji, gdy odwołanie następuje na wniosek Ubezpieczonego;

f) wygaśnięcia kontraktu menedżerskiego lub żołnierskiego lub marynarskiego lub rozwiązania innych przyczyn, niż wypowiedzenie przez Ubezpieczonego lub za porozumieniem stron;

2) Ubezpieczony nie pozostaje w jakimkolwiek stosunku pracy lub nie wykonuje innej pracy zarobkowej lub nie prowadzi działalności gospodarczej przez okres co najmniej 30 dni liczony od następnego dnia po dacie wskazanej w ppkt 1 ;

3) Ubezpieczony uzyskał status bezrobotnego."1 .

${ }^{1} \S 2$ ust. 47. Ogólne warunki ubezpieczenia spłaty kredytu hipotecznego, pożyczki hipotecznej na wypadek utraty źródła dochodu, inwalidztwa w następstwie nieszczęśliwego wypadku i leczenia szpitalnego dla klientów PKO Banku Polskiego SA lub PKO Banku Hipotecznego SA, PKO Towarzystwo Ubezpieczeń SA, OWU/UPKH/2018-1, s. 3. 
Utrata źródeł dochodu z działalności gospodarczej oznacza „utratę dochodu z działalności gospodarczej prowadzonej na terytorium Rzeczypospolitej Polskiej, o ile zostały spełnione łącznie poniższe kryteria:

1) nastąpiło zakończenie wykonywania działalności gospodarczej;

2) Ubezpieczony nie prowadzi jakiejkolwiek działalności gospodarczej lub nie wykonuje innej pracy zarobkowej lub nie pozostaje w stosunku pracy przez okres co najmniej 30 dni liczonych od dnia następnego po dacie o której mowa w ppkt 1 ;

3) Ubezpieczony uzyskał status bezrobotnego"2.

Z kolei utrata dochodu z innej pracy zarobkowej oznacza „utratę dochodu (...) o ile zostały spełnione łącznie poniższe kryteria:

1) Utrata dochodu nastąpiła z którejkolwiek z poniższych przyczyn:

a) rozwiązania umowy leżącej u podstaw innej pracy zarobkowej, której stroną jest Ubezpieczony nieposiadający ustalonego decyzją uprawnionego organu prawa do świadczeń emerytalnych lub rentowych z ubezpieczenia społecznego lub;

b) rozwiązania stosunku pracy lub leżącej u podstaw innej pracy zarobkowej umowy, których stroną jest Ubezpieczony posiadający ustalone decyzją uprawnionego organu prawo do świadczeń emerytalnych lub rentowych z ubezpieczenia społecznego o ile rozwiązanie umowy agencyjnej albo umowy zlecenia albo umowy o dzieło nastąpiło z innych przyczyn, niż wypowiedzenie albo odstąpienie od tej umowy przez Ubezpieczonego albo rozwiązanie jej za porozumieniem stron, zaś w przypadku Ubezpieczonego świadczącego pracę $\mathrm{w}$ ramach stosunku pracy i posiadającego ustalone prawo do świadczeń emertytalnych lub rentowych z ubezpieczenia społecznego, o ile rozwiązanie stosunku pracy nastąpiło z przyczyn, o których mowa w OWU.

2) Ubezpieczony nie pozostaje w jakimkolwiek stosunku pracy lub nie świadczy usług na podstawie umowy agencyjnej lub umowy zlecenia lub umowy o dzieło lub nie prowadzi działalności gospodarczej przez okres co najmniej 30 dni liczony od następnego dnia po dacie wskazanej w ppkt 1;

3) Ubezpieczony uzyskał status osoby poszukującej pracę."

${ }^{2} \S 2$ ust. 46. Ogólne warunki ubezpieczenia spłaty kredytu hipotecznego, pożyczki hipotecznej na wypadek utraty źródła dochodu, inwalidztwa w następstwie nieszczęśliwego wypadku i leczenia szpitalnego dla klientów PKO Banku Polskiego SA lub PKO Banku Hipotecznego SA, PKO Towarzystwo Ubezpieczeń SA, OWU/UPKH/2018-1, s. 3.

${ }^{3} \S 2$ ust. 48 Ogólne warunki ubezpieczenia spłaty kredytu hipotecznego, pożyczki hipotecznej na wypadek utraty źródła dochodu, inwalidztwa w następstwie nieszczęśliwego wypadku i leczenia szpitalnego dla klientów PKO Banku Polskiego SA lub PKO Banku Hipotecznego SA, PKO Towarzystwo Ubezpieczeń SA, OWU/UPKH/2018-1, s. 3-4. 
Pojęcia utraty źródła dochodu zawężają zakres ochrony. Zawężenie to jest powtórzone i rozszerzone w dalszej części o.w.u. w $\S 6$, dotyczącym wyłączenia odpowiedzialności.

Zgodnie z jego treścią, okoliczności wyłączające odpowiedzialność są następujące ${ }^{4}$ :

1) jeżeli rozwiązanie stosunku pracy nastąpiło na wniosek ubezpieczonego lub z winy ubezpieczonego lub na skutek rozwiązania umowy o pracę przez pracodawcę bez wypowiedzenia;

2) gdy utrata pracy nastąpiła w wyniku odmowy przyjęcia przez ubezpieczonego zaproponowanych mu nowych warunków pracy lub płacy;

3) jeżeli utrata pracy jest kolejną utratą pracy występującą na skutek rozwiązania stosunku pracy z tym samym pracodawcą, a ubezpieczyciel wypłacił świadczenie $\mathrm{z}$ tytułu poprzedniej utraty pracy;

4) jeżeli w dniu zawarcia umowy ubezpieczenia ubezpieczony pozostawał w okresie wypowiedzenia stosunku pracy lub został odwołany ze stanowiska lub funkcji w przypadku zatrudnienia na podstawie stosunku służbowego;

5) jeżeli ubezpieczony najpóźniej w momencie zawarcia umowy ubezpieczenia został poinformowany przez pracodawcę o grupowych zwolnieniach obejmujących ubezpieczonego;

6) jeżeli ubezpieczony najpóźniej w momencie zawarcia umowy ubezpieczenia został poinformowany przez pracodawcę o zamiarze likwidacji stanowiska pracy;

7) jeżeli rozwiązanie stosunku pracy nastąpiło w drodze porozumienia stron;

8) jeżeli ubezpieczony w trakcie ochrony ubezpieczeniowej nabył prawa do emerytury lub renty z Funduszu Ubezpieczeń Społecznych;

9) jeżeli ubezpieczonemu w trakcie ochrony ubezpieczeniowej wygasła umowa zawarta na czas określony lub ustał stosunek pracy wskutek upływu terminu jego obowiązywania;

10)jeżeli utrata źródła dochodu nastąpiła w wyniku rozwiązania stosunku pracy z przedsiębiorcą, którego wspólnikiem jest krewny lub powinowaty ubezpieczonego do drugiego stopnia włącznie;

11)jeżeli ubezpieczony najpóźniej w momencie zawarcia umowy ubezpieczenia był poinformowany o złożonym przez drugą stronę stosunku pracy, umowy agencyjnej, umowy zlecenia lub umowy o dzieło, albo innej umowy cywilnoprawnej, wniosku o ogłoszenie upadłości pracodawcy z powodu braku wystarczającego majątku na zaspokojenie kosztów postępowania upadłościowego;

${ }^{4} \S 6$ ust. 1-12. Ogólne warunki ubezpieczenia spłaty kredytu hipotecznego, pożyczki hipotecznej na wypadek utraty źródła dochodu, inwalidztwa w następstwie nieszczęśliwego wypadku i leczenia szpitalnego dla klientów PKO Banku Polskiego SA lub PKO Banku Hipotecznego SA, PKO Towarzystwo Ubezpieczeń SA, OWU/UPKH/2018-1, s. 5. 
12)w okresie 6 miesięcy poprzedzających zawarcie umowy ubezpieczenia nie prowadził nieprzerwanie działalności gospodarczej lub w okresie tym został złożony wniosek o upadłość.

Świadczenie z tytułu utraty źródeł dochodu jest świadczeniem miesięcznym (dla zdarzeń utraty pracy i utraty dochodu z działalności gospodarczej) oraz jednorazowym dla zdarzeń z tytułu utraty dochodu z innej pracy zarobkowej, należnym wypłacanym wyłącznie raz w całym okresie ubezpieczenia. Wysokość świadczenia odpowiada udziałowi procentowemu ubezpieczonego w kwocie najbliższej raty kredytu (jeżeli kredytobiorców jest więcej niż jeden, o.w.u. dopuszcza maksymalnie dwóch ubezpieczonych).

Odpowiedzialność ubezpieczyciela ograniczona jest do równowartości 6 rat w przypadku jednego zdarzenia ubezpieczeniowego polegającego na utracie pracy lub utracie dochodu z działalności gospodarczej. Maksymalna wysokość świadczenia miesięcznego jest równa udziałowi procentowemu ubezpieczonego w najbliższej racie, jednakże nie więcej niż 30000 PLN. Łączna wysokość świadczeń miesięcznych w całym okresie ubezpieczenia nie może przekroczyć kwoty stanowiącej równowartość 12 rat oraz nie może być wyższa niż $360000 \mathrm{zl}$, bez względu na liczbę przypadków utraty pracy oraz utraty dochodu z działalności gospodarczej5.

Warunki ubezpieczenia spłaty kredytów Banku Pekao są zawarte w tym samym o.w.u., co ubezpieczenie na życie. Pojęcie „utrata dochodu” poza utratą pracy obejmuje również czasową niezdolność do pracy.

Utrata dochodu oznacza zdarzenie, które polega na wystąpieniu u ubezpieczonego utraty pracy lub czasowej niezdolności do pracy, przy czym utrata pracy musi nastąpić wskutek wypowiedzenia lub rozwiązania stosunku pracy przez pracodawcę .

Zakres ubezpieczenia zależny jest od statusu ubezpieczonego w chwili zawarcia umowy ubezpieczenia oraz w trakcie jej trwania.

Ubezpieczyciel dzieli ubezpieczonych na trzy kategorie:

- ubezpieczony, zatrudniony na podstawie stosunku pracy zawartego na czas nieokreślony,

- ubezpieczony zatrudniony na podstawie stosunku pracy zawartego na czas określony lub prowadzący działalność gospodarczą lub wykonujący działalność zarobkową w innej formie,

${ }^{5} \S 10$ ust. 3 pkt. 2-3. Ogólne warunki ubezpieczenia spłaty kredytu hipotecznego, pożyczki hipotecznej na wypadek utraty źródła dochodu, inwalidztwa w następstwie nieszczęśliwego wypadku i leczenia szpitalnego dla klientów PKO Banku Polskiego SA lub PKO Banku Hipotecznego SA, PKO Towarzystwo Ubezpieczeń SA, OWU/UPKH/2018-1, s. 5.

${ }^{6} \S 1$ ust. 3 pkt. 33. Ubezpieczenie dla Kredytobiorców Kredytów Mieszkaniowych banku Pekao S.A. Sopockie Towarzystwo Ubezpieczeń Ergo Hestia SA, KH-PEKAO 01/18), s. 4. 
- ubezpieczony niezdolny do pracy lub posiadający prawo do emerytury (niezależnie od osiągania przez niego dochodu) albo nieosiągający dochodu.

Jako utratę pracy o.w.u. definiuje zdarzenie polegające na:

a) utracie zatrudnienia wskutek rozwiązania za wypowiedzeniem przez pracodawcę stosunku pracy zawartego z Ubezpieczonym na czas nieokreślony;

b) niepozostawaniu w innym stosunku pracy przez okres minimum 61 dni liczonych od daty rozwiązania stosunku pracy, o którym mowa pod lit. a);

c) uzyskaniu, w wyniku rozwiązania stosunku pracy, o którym mowa pod lit. a) przez Ubezpieczonego: - statusu Bezrobotnego oraz uprawnienia do pobierania zasiłku dla Bezrobotnych w rozumieniu odpowiednich przepisów prawa polskiego, albo - statusu Poszukującego Pracy - w przypadku osób, które na podstawie obowiązujących przepisów prawa nie mogą uzyskać statusu Bezrobotnego oraz uprawnienia do zasiłku (tj. m.in. osób, które są Niezdolne do Pracy lub posiadają prawo do emerytury), przy czym warunki określone pod lit. a)-c) muszą zostać spełnione łącznie, z zastrzeżeniem wyłączeń odpowiedzialności Ubezpieczyciela określonych w $\S 9$ ust. 1 niniejszych OWU"7.

Warunki określone w lit. a)-c) muszą zostać spełnione łącznie.

Czasowa niezdolność do pracy to „niemożność świadczenia dotychczasowej pracy, świadczonej na podstawie stosunku pracy zawartego na czas określony lub w formie prowadzonej działalności gospodarczej lub wykonywania działalności zarobkowej w innej formie (z wyłączeniem stosunku pracy zawartego na czas nieokreślony), przez Ubezpieczonego trwająca nieprzerwanie przez okres minimum 61 dni liczonych od pierwszego dnia niezdolności do pracy potwierdzona stosownym zaświadczeniem lekarskim (druk ZUS ZLA), z zastrzeżeniem wyłączeń odpowiedzialności Ubezpieczyciela określonych w § 9 ust. 2 niniejszych OWU"8. W przypadku utraty dochodu polegającej na wystąpieniu czasowej niezdolności do pracy potrzebne jest m.in. zaświadczenie lekarskie (druk ZUS ZLA) określające przewidywany okres przerwy w pracy oraz jeżeli miał miejsce pobyt w szpitalu, dodatkowa historia pobytu w szpitalu.

Ochrona utraty dochodu $\mathrm{z}$ tytułu utraty pracy przysługuje zatrudnionym na podstawie stosunku pracy zawartego na czas nieokreślony oraz ubezpieczonym niezdolnym do pracy lub posiadającym prawo do emerytury (niezależnie od osiągania przez niego dochodu) albo nieosiągającym dochodu. Zgodnie z definicjami pojęć $\mathrm{z}$ ubezpieczenia utraty dochodu $\mathrm{z}$ tytułu utraty pracy są wyłączeni zatrudnieni na podstawie stosunku pracy zawartego na czas określony lub prowadzący działalność gospodarczą lub wykonujący działalność zarobkową w innej formie. Tej grupie przysługuje ochrona utraty dochodu z tytułu czasowej niezdolności do

$7 \S 1$ ust. 3 pkt. 34. Ubezpieczenie dla Kredytobiorców Kredytów Mieszkaniowych banku Pekao S.A. Sopockie Towarzystwo Ubezpieczeń Ergo Hestia SA, KH-PEKAO 01/18), s. 4.

8 § 1 ust. 3 pkt. 4. Ubezpieczenie dla Kredytobiorców Kredytów Mieszkaniowych Banku Pekao S.A., Sopockie Towarzystwo Ubezpieczeń Ergo Hestia SA, KH-PEKAO 01/18), s. 2. 
pracy. Zakres ochrony ubezpieczonych, zatrudnionych na podstawie stosunku pracy zawartego na czas nieokreślony, poszerzyłby się istotnie, gdyby obejmował nie tylko utratę dochodu z tytułu utraty pracy, ale także z tytułu czasowej niezdolności do pracy.

W odniesieniu do świadczenia z tytułu utraty dochodu polegającej na wystąpieniu utraty pracy, odpowiedzialność ubezpieczyciela jest wyłączona w przypadku, gdy ${ }^{9}$ :

- wypowiedzenie stosunku pracy przez pracodawcę nastąpiło przed upływem 90 dni od daty zawarcia umowy ubezpieczenia,

- utrata pracy nastąpiła w związku z rozwiązaniem stosunku pracy w wyniku jego wypowiedzenia przez ubezpieczonego,

- utrata pracy nastąpiła w związku z rozwiązaniem stosunku pracy za porozumieniem stron,

- utrata pracy nastąpiła w wyniku wypowiedzenia warunków pracy lub płacy przez ubezpieczonego,

- utrata pracy nastąpiła $\mathrm{w}$ związku $\mathrm{z}$ rozwiązaniem przez pracodawcę stosunku pracy z ubezpieczonym bez wypowiedzenia.

W odniesieniu do świadczenia z tytułu utraty dochodu polegającej na wystąpieniu czasowej niezdolności do pracy odpowiedzialność ubezpieczyciela jest wyłączona w przypadku, gdy zajście zdarzenia ubezpieczeniowego nastąpiło w wyniku następstwa ${ }^{10}$ :

- samobójstwa lub usiłowania popełnienia samobójstwa - jeżeli samobójstwo lub usiłowanie samobójstwa nastąpiło w okresie do 2 lat od daty zawarcia umowy ubezpieczenia,

- działania ubezpieczonego w stanie nietrzeźwości, po użyciu alkoholu, po użyciu narkotyków lub innych substancji odurzających,

- aktów wojny (w tym wojny domowej), czynnego uczestnictwa ubezpieczonego w zamieszkach, przestępstwach, aktach terroryzmu lub sabotażu,

- eksplozji atomowej oraz napromieniowania,

- poddania się przez ubezpieczonego zabiegom o charakterze medycznym poza kontrolą lekarską lub uprawnionych do tego osób,

- prowadzenia przez ubezpieczonego pojazdu mechanicznego bez wymaganych uprawnień,

${ }^{9} \S 9$ ust. 1. Ubezpieczenie dla Kredytobiorców Kredytów Mieszkaniowych Banku Pekao S.A., Sopockie Towarzystwo Ubezpieczeń Ergo Hestia SA, KH-PEKAO 01/18), s. 9.

$10 \S 9$ ust. 2. Ubezpieczenie dla Kredytobiorców Kredytów Mieszkaniowych Banku Pekao S.A., Sopockie Towarzystwo Ubezpieczeń Ergo Hestia SA, KH-PEKAO 01/18), s. 9-10. 
- uczestnictwa ubezpieczonego w locie, w charakterze pilota, członka załogi lub pasażera samolotu wojskowego lub prywatnego nieposiadającego licencji na przewóz pasażerów,

- umyślnego samookaleczenia lub uszkodzenia ciała na prośbę ubezpieczonego.

Świadczenie z tytułu utraty dochodu polegającej na wystąpieniu utraty pracy jest świadczeniem miesięcznym wypłacanym w kwocie raty kredytu, dla ubezpieczonych, zatrudnionych na podstawie stosunku pracy zawartego na czas nieokreślony. Natomiast dla ubezpieczonych niezdolnych do pracy lub posiadających prawo do emerytury (niezależnie od osiągania przez niego dochodu) albo nieosiągających dochodu, jest świadczeniem jednorazowym wypłacanym w kwocie raty kredytu. Łączna kwota świadczeń miesięcznych z tytułu utraty dochodu przez ubezpieczonego w okresie ubezpieczenia nie może przekroczyć kwoty odpowiadającej 12 ratom kredytu. Maksymalny poziom świadczeń wynoszący tylko 12 rat kredytu w przypadku kredytu hipotecznego oznacza słabą ochronę ubezpieczeniową.

Podsumowując przeprowadzoną analizę porównawczą poziomu ochrony, który został zdefiniowany przez zakres ochrony (rodzaj zdarzeń) oraz definicje pojęć, można wysunąć następujące wnioski.

Zakres ochrony do kredytów PKO BP jest szerszy aniżeli do kredytów Banku Pekao. Bank Pekao stosuje poszerzoną definicję utraty dochodu o czasową niezdolność do pracy, ale nie oferuje ochrony w wyniku inwalidztwa w następstwie nieszczęśliwego wypadku i leczenia szpitalnego. Bank Pekao oferuje wartościowe ubezpieczenie dochodu z tytułu czasowej niezdolności do pracy, ale nie dla ubezpieczonych zatrudnionych w ramach stosunku pracy na czas nieokreślony.

Przyjęte przez ubezpieczycieli w o.w.u. definicje pojęć istotnie zawężają zakres ochrony z tytułu utraty źródeł dochodu. W obydwu bankach ochrony tej pozbawieni są ubezpieczeni zatrudnieni na podstawie kodeksu pracy lub kodeksu cywilnego, jeżeli rozwiązanie umowy nastąpiło przez wypowiedzenie albo odstąpienie od umowy przez ubezpieczonego lub jej rozwiązanie nastąpiło za porozumieniem stron. Ochrona przysługuje tylko wtedy, gdy rozwiązanie umowy pracy nastąpiło za wypowiedzeniem umowy przez zatrudniającego (pracodawcę). Ponadto, aby być uprawnionym do świadczenia ubezpieczeniowego trzeba być zarejestrowanym w urzędzie pracy i mieć status bezrobotnego (w przypadku Banku Pekao dodatkowo z prawem do zasiłku) lub poszukującego pracę. Ważne dla ochrony kredytobiorców Banku Pekao jest to, że w przypadku świadczeń z tytułu wystąpienia utraty pracy odpowiedzialność jest wyłączona, jeżeli wypowiedzenie stosunku pracy przez pracodawcę nastąpiło przed upływem 90 dni od daty zawarcia umowy ubezpieczenia. 


\section{PODSUMOWANIE}

Analiza ogólnych warunków ubezpieczenia. w ubezpieczeniach dodawanych do kredytów konsumenckich oferowanych przez PKO BP i Bank Pekao pokazała, że przyjęte we wzorcu definicje pojęć, zakres odpowiedzialności ubezpieczyciela, charakter wyłączeń i ograniczeń odpowiedzialności oraz wysokość świadczeń istotnie ograniczają potencjalny poziom ochrony.

Powyższa analiza zakresu ochrony ubezpieczeniowej w wybranych bankach dowodzi, że oferowane ogólne warunki ubezpieczenia cechują się wysokim stopniem skomplikowania. $Z$ powyższego wynika, że konsument może mieć problem z porównaniem ofert i wybraniem ubezpieczenia użytecznego, czyli dopasowanego do jego potrzeb. Pozwoliło to na potwierdzenie tezy, iż postanowienia wzorców umów ubezpieczenia powiązanych z umową kredytu konsumenckiego cechuje wysoki stopień skomplikowania i tym samym utrudniają konsumentowi dokonania oceny i wyboru użytecznego ubezpieczenia.

Przeprowadzona analiza o.w.u. pozwoliła na określenie ram ochrony ubezpieczeniowej. Rzeczywisty poziom ochrony może się różnić od tego wynikającego z zapisów formalnych. Ustalenie rzeczywistego poziomu ochrony wymagałoby uwzględnienia danych na temat realizacji umów przez ubezpieczycieli. Pomocne w tym zakresie byłyby dane gromadzone przez Rzecznika Finansowego w ramach skarg zgłaszanych przez niezadowolonych klientów.

\section{BIBLIOGRAFIA}

Bednarek M., Mikłaszewicz P., 2020, Wzorce umów, [w:] K. Osajda (red.), Prawo zobowiązań część ogólna. System Prawa Prywatnego, t. 5, C.H. Beck, Warszawa.

Celczyńska A., Korytkowska D., Piechota A., 2016, Ubezpieczenia, [w:] A. Celczyńska (red.), Poradnik konsumenta ustug finansowych, Uniwersytet Łódzki, Łódź.

Kościelniak M., 2011, Dyrektywy wykładnie w odniesieniu do wzorców umownych, „Monitor Ubezpieczeniowy", nr 46, https://rf.gov.pl/publikacje/artykuly-pracownikow-i-wspolpracownikow/Mateusz_Koscielniak__Dyrektywy_wykladni_w_odniesieniu_do_wzorcow_umownych___Monitor_Ubezpieczeniowy_nr_46__wrzesien_20_20591 [dostęp 4.05.2020].

Krajewski M., 2016, Skutki niedoręczenia ogólnych warunków ubezpieczenia, „Wiadomości Ubezpieczeniowe", nr 3.

Kwiecień I., 2016, Umowa i stosunek ubezpieczenia, [w:] W. Ronka-Chmielowiec (red.), Ubezpieczenia, C.H.Beck, Warszawa.

Łętowska E., 2004, Europejskie prawo umów konsumenckich, C.H. Beck, Warszawa.

Mikłaszewicz P., 2020, Komentarz, [w:] K. Osajda (red.), Kodeks cywilny. Komentarz. Tom II. Zobowiązania, C.H. Beck, Warszawa.

Nowak K., 2019, Ubezpieczenie nieruchomości z cesją praw jako zabezpieczenie spłaty kredytu hipotecznego $w$ kontekście interesu konsumenta, „Finanse i Prawo Finansowe”, nr 4(24). 
Nowak P., 2019, Ubezpieczenie kredytu gotówkowego - korzyścia dla kredytobiorcy czy kredytodawcy?, [w:] B. Gnela, E. Sługocka-Krupa, M. Szaraniec, A. Viglianisi Ferraro (red.), Prawo konsumenckie $w$ Polsce oraz innych państwach UE. Zagadnienia wybrane, C.H.Beck, Warszawa.

Nowak P., 2020, Ubezpieczenie niskiego wktadu własnego jako źródto roszczeń konsumenckich, [w:] M. Jagielska, E. Sługocka-Krupa, K. Podgórski (red.), Dochodzenie roszczeń konsumenckich. Nowy lad dla konsumenta, C.H.Beck, Warszawa.

Ogólne warunki ubezpieczenia spłaty kredytu hipotecznego, pożyczki hipotecznej na wypadek utraty źródła dochodu, inwalidztwa w następstwie nieszczęśliwego wypadku i leczenia szpitalnego dla klientów PKO Banku Polskiego SA lub PKO Banku Hipotecznego SA, PKO Towarzystwo Ubezpieczeń SA, OWU/UPKH/2018-1

Orlicki M., 2010, Regulacja umowy ubezpieczenia, [w:] J. Handschke, J. Monkiewicz (red.), Ubezpieczenia podręcznik akademicki, Poltext, Warszawa.

Orlicki M., 2015, Rozwiazania konsumenckie w nowej ustawie o działalności ubezpieczeniowej i reasekuracyjnej, [w:] J. Monkiewicz, M. Orlicki (red.), Ochrona konsumentów na rynku ubezpieczeniowym $w$ Polsce, Poltext, Warszawa.

Orlicki M., 2016, Kilka uwag o technice tworzenia ogólnych warunków ubezpieczenia, „Wiadomości Ubezpieczeniowe", nr 1.

Pokrzywniak J., 2016, Ogólne warunki ubezpieczenia $w$ świetle kodeksu cywilnego oraz ustawy o działalności ubezpieczeniowej i reasekuracyjnej - zagadnienia wybrane, „Prawo Asekuracyjne", nr 2(87).

Przybitnikowski J.W., 2019, Metody badania jakości usług w procesie zarządzania rynkiem ubezpieczeń majątkowych, Wydawnictwo Uniwersytetu Jana Kochanowskiego, Kielce.

Ranking przyjazny bank „Newsweeka”, 2019, „Newsweek”, nr 40.

Serwach M., 2014, Swoboda woli stron umowy ubezpieczenia czy jej ustawowa nadregulacja, [w:] M. Serwach (red.), Rynek ubezpieczeniowy, nadregulacja czy niedoregulowanie, Wydawnictwo Uniwersytetu Łódzkiego, Łódź.

Ubezpieczenie dla Kredytobiorców Kredytów Mieszkaniowych banku Pekao S.A. Sopockie Towarzystwo Ubezpieczeń Ergo Hestia SA, KH-PEKAO 01/18.

Ustawa z dnia 11 września 2015 r. o działalności ubezpieczeniowej i reasekuracyjnej, Dz.U. 2019, poz. $381 \mathrm{ze} \mathrm{zm}$.

Ustawa z dnia 23 kwietnia 1964 r., Kodeks cywilny, Dz.U. 2019, poz. 1145 ze zm.

Wałachowska M., 2016, Wzorce umowne po wejściu w życie nowej ustawy o działalności ubezpieczeniowej i reasekuracyjnej. Zagadnienia wybrane, „Wiadomości Ubezpieczeniowe”, nr 3.

Wąsiewicz A., 1997, Umowa ubezpieczenia, [w:] A. Wąsiewicz (red.), Ubezpieczenia w gospodarce rynkowej, Oficyna Wydawnicza Branta, Bydgoszcz.

Więcko-Tułowiecka M., 2014, Ochrona konsumentów w umowach ubezpieczenia, LexisNexis, Warszawa.

Wyrok Sądu Najwyższego z dnia 18 marca 2003 r., sygn.. akt IV CKN 1858/00.

Zoll F., 1998, Natura prawna wzorców umownych, „PiP”, nr 5.

XXIV Ranking Banków, 2019, „Bank”, nr 6. 


\title{
SCOPE OF CONSUMER PROTECTION IN THE PAYMENT PROTECTION INSURANCE OFFERED BY SELECTED BANKS
}

\begin{abstract}
It is common practice in the financial market for banks to combine credit with insurance in their offers. Credit insurance is a combination of two financial services - a banking and an insurance service Insurance distribution with loans is a natural phenomenon. Credit and insurance are complementary products. Instalment is generally a serious expense in the household budget. As a consequence of taking out a loan, risk of losing borrower's ability to fulfill financial obligations increase. With this end in view borrower has insurance as an instrument to defusing the risk of borrowing. Banks treat an insurance agreement as a collateral for the repayment of a loan, which is an additional security. On the other hand this instrument can be helpful for the consumer financial difficulties due to work loss or permanent disability. The purpose of insurance added to loan is to reduce the risk of the borrower's inability to repay the loan and to ensure the safety of the insured or beneficiary of insurance policy. Insurance is not a typical product on the financial market because the policy holder acquires an abstract guarantee of insurance benefit in exchange for an insurance premium. The aim of the article is to compare and assess insurance the scope of consumer (policyholder) protection based on general insurance conditions in payment protection insurance added to consumer loan offered by the two largest banks in Poland. Comparative analysis of the scope of consumer was based on this few category: subject matter of insurance, definition of event covered by the insurance company, type of insurance benefit and exclusions and limitations of lability.
\end{abstract}

Keywords: mortgage, insurance, collateral of loans, bancassurance, consumer protection. 